\title{
The impact of competition on regional food security (the case of the milk and dairy market in the Republic of Tatarstan)
}

\author{
A. I. Sabirova ${ }^{1} \bowtie$, M. M. Nizamutdinov ${ }^{2}$, A. R. Safiullin ${ }^{1}$, F. I. Kharisova ${ }^{1}$ \\ ${ }^{1}$ Kazan Federal University, Kazan, Russia; e-mail: aigylkinyes@mail.ru \\ ${ }^{2}$ Kazan State Agrarian University, Kazan, Russia
}

\begin{abstract}
Regional food markets are important structural elements of the national market. Development of the market environment is one of the key methods of stimulating food production. As the agro-industrial policy changes its focus from import substitution towards export-oriented production, the role of competition in the agricultural sphere becomes particularly prominent. The authors propose a new indicator characterizing the level of concentration of producers on the market - the Herfindahl-Hirschman Index (HHI) for the share of gross profit of economic entities. This article is aimed at giving a theoretical justification of this approach and at providing practical recommendations for the development of regional food markets based on the regulation of food producer concentration levels. Multi-dimensional statistical calculations were used to test the hypothesis that the development of large economic entities (including monopolies) has a positive impact on the affordability and accessibility of locally produced foods. The authors measured the strength of the correlation between the socio-economic indicators that affect regional food security by using the case of the milk and dairy market in the Republic of Tatarstan. The proposed methodology is based on the decision matrix method applied to analyze the situation in local food markets, which gives us a better understanding of the situation in the whole region regarding the accessibility and affordability of foods. The correlation-regression analysis enabled us to integrate the indicators that show the impact of competition on affordability of foods with those that show the impact of producers' efficiency on accessibility of foods in the region. The proposed approach considers profitability of economic entities, accessibility of foods and competition on the producer market and can thus be used to enhance food security by revealing the optimal priority areas for governmental policies and programs on the national, regional and local levels.
\end{abstract}

\section{KEYWORDS}

food market, food security, regional markets, local market, industry, competition, concentration, regional development, industrial policy, competition policy, regional policy

\section{FOR CITATION}

Sabirova, A. I.,

Nizamutdinov, M. M.,

Safiullin, A. R., \&

Kharisova, F. I. (2019) The

impact of competition on regional food security (the case of the milk and dairy market in the Republic of Tatarstan). R-economy, 5(3), 137-143. doi: 10.15826/recon.2019.5.3.014

\section{Влияние конкуренции на региональную продовольственную безопасность (пример рынка молока и молочной Республики Татарстан)}

\author{
А. И. Сабирова ${ }^{1} \bowtie$, М. М. Низамутдинов ${ }^{2}$, А. Р. Сафиуллин ${ }^{1}$, Ф. И. Харисова ${ }^{1}$ \\ ${ }^{1}$ Казанский федеральньй университет, Казань, Россия; e-mail: aigylkinyes@mail.ru \\ ${ }^{2}$ Казанский государственный аграрный университет, Казань, Россия
}

\section{АННОТАЦИЯ}

Региональные продовольственные рынки являются важными структурными элементами национального рынка. Развитие рыночной среды является одним из ключевых способов стимулирования производства продуктов питания. Поскольку агропромышленная политика меняет фокус с импортозамещения на экспортно-ориентированное производство, роль конкуренции в сельскохозяйственной сфере становится особенно заметной. Авторы предлагают новый показатель, характеризующий уровень концентрации производителей на рынке, - индекс Херфиндаля-Хиршмана (HНI) для доли валовой прибыли хозяйствующих субъектов. Цель данной статьи - дать теоретическое обоснование этого подхода и дать практические рекомендации по развитию региональных продовольственных рынков на основе регулирования уровней концентрации производителей продуктов питания. Многомерные статистические расчеты использовались для проверки гипотезы о том, что развитие крупных экономических субъектов (включая монополии) оказывает положительное влияние на доступность продуктов местного производства. Авторы измерили степень корреляции между социально-экономическими показателями, влияющими на региональную продовольственную безопасность, на примере рынка молока (๔) A. I. Sabirova, M. M. Nizamutdinov, A. R. Safiullin, F. I. Kharisova, 2019

\section{Ключевые слова}

продовольственный рынок, продовольственная безопасность, региональные рынки, местный рынок, промышленность, конкуренция, концентрация, региональное развитие, промышленная политика, конкурентная политика, региональная политика 
и молокопродуктов в Республике Татарстан. Предлагаемая методология основана на методе матрицы решений, применяемом для анализа ситуации на местных продовольственных рынках, что позволяет нам лучше понять ситуацию во всем регионе в отношении доступности продуктов питания. Корреляционно-регрессионный анализ позволил нам объединить показатели, которые показывают влияние конкуренции на доступность продуктов питания, с показателями, которые показывают влияние эффективности производителей на доступность продуктов питания в регионе. Предлагаемый подход учитывает прибыльность хозяйствующих субъектов, доступность продуктов питания и конкуренцию на рынке производителей и, таким образом, может использоваться для повышения продовольственной безопасности путем выявления оптимальных приоритетных областей государственной политики и программ на национальном, региональном и местном уровнях.

\section{ДЛя ЦИТИРОВАНИЯ}

Sabirova, A. I.

Nizamutdinov, M. M.,

Safiullin, A. R., \&

Kharisova, F. I. (2019) The

impact of competition on regional food security (the case of the milk and dairy market in the Republic of Tatarstan). R-economy, 5(3), 137-143. doi: 10.15826/recon.2019.5.3.014

\section{Introduction}

National food security is entirely dependent on regional food markets. Regional authorities are expected to design their own strategies of developing their food markets by following the federal legislation ${ }^{1}$ and taking into account the natural, climatic, economic and other characteristics of their territories. Some Russian regions, such as Moscow, St. Petersburg, Tatarstan, Bashkortostan, Nizhny Novgorod, Sverdlovsk, and Ulyanovsk, made the principles of food security a part of their regional legislation. In the light of the changing external and internal conditions and the current geopolitical situation, for example, Russia's entry into the WTO and the intensification of the integration processes in the Eurasian Economic Union, the Russian Ministry of Agriculture and other governmental agencies are now developing a draft for the new Food Security Doctrine ${ }^{2}$. According to this Doctrine, the state is responsible for maintaining a certain guaranteed level of food security in the country and it is necessary to enhance trust and cooperation between the participants of the national food market.

In the light of the above, this study aims to give a theoretical justification of the proposed approach to investigating food security on the local and regional levels and to provide practical recommendations for the development of regional food markets based on the regulation of food producer concentration.

${ }^{1}$ Decree of the President of the Russian Federation of 30.01.2010 No. 120 "On the Food Security Doctrine of the Russian Federation".

${ }^{2}$ Draft Decree of the President of the Russian Federation "On Amendments to the Food Security Doctrine of the Russian Federation Signed by the President of the Russian Federation on 30 January 2010 No. 120" (prepared by the Ministry of Agriculture of Russia, 25.01.2018). Retrieved from: https:// www.garant.ru/products/ipo/prime/doc/56641501

\section{Literature review}

Food security is forecast to become the main global issue in the nearest decades ${ }^{3}$ as it is expected that by 2050, there will be 9.6 billion people in the world ${ }^{4}$, which means that food production will have to increase by $70-110 \%$ to feed the global population [1].

Economic assessment and realization of the strategic potential of the agricultural sector has been the key goal of state regulation in the last two decades ${ }^{5}$. It has also become a central strategy for the development of state and non-state programs [2]. Assessment of the regional sustainable development encompasses the environmental, economic and social aspects ${ }^{6}$ and relies on such economic indicators as food demand, population growth rate and the rates of growth of factor productivity in the region $[3 ; 4]$.

In the recent decade, there has been an upsurge of scholarly interest in small business and entrepreneurship in agriculture and farming ${ }^{7}$. At the same time, the national competition policy and agro-industrial policy should take into consideration the interregional differences in living standards and the differentiation of economic potential.

3 The World and Food Security (2016). Retrieved from: http://www.fao.org/3/r-i5591r.pdf

World Population Prospects 2017. Retrieved from: $\quad$ http://search.un.org/results.php?query=+Population+Division+\%5BUNDESA \%5D \%2C+2013\&amp;tpl=desa\&amp;lang $=$ en

FAOSTAT (2016) Retrieved from: http://faostat3.fao. org/home/E

${ }^{6}$ Decree of the President of the Russian Federation of 01.04.1996 No. 440 "On the Concept of Transition of the Russian Federation to Sustainable Development". Retrieved from: http://www.consultant.ru/cons/cgi/online. cgi? req $=$ doc \&base $=\mathrm{EXP} \& \mathrm{n}=233558 \# 037053171693040987$

Smallholders, food security, and the environment by the International Fund for Agricultural Development (IFAD) (2013) Retrieved from: https://www.ifad.org/documents/38714170/39135645/smallholders report.pdf/133e8903-0204-4e7d-a780-bca847933f2e 


\section{Methodology}

The development of competition is considered as a priority both by economists and by state policy-makers in all spheres (with the exception of military monopoly and natural monopolies). According to Joseph Schumpeter, firms in highly concentrated markets can redistribute resources more efficiently than in highly competitive markets [5]. Therefore, hypothetically, large economic entities may have a positive impact on the affordability and accessibility of foods due to the economy of scale, reduced production costs and the production of highly processed foods. We are going to test this hypothesis by applying mathematical and statistical methods (regression analysis with Gretl software) to evaluate the interrelation of the above-described indicators. Our analysis will focus on the case of local food markets in Tatarstan and use the official data from the Federal State Statistics Service and the Ministry of Agriculture and Food of the Republic of Tatarstan.

The Russian Ministry of Agriculture changed the methods of calculating food security indicators and introduced a new indicator to measure the extent to which domestic production can satisfy the demands of the market. In addition to this, we propose an indicator "index of food item accessibility" calculated according to Formula 1:

$$
F_{i}=\frac{V \cdot k_{\square}}{P \cdot N_{\square}},
$$

where $F_{i}$ is the index of accessibility of the $i^{\text {th }}$ food item;

$V$ is the production volume of this food item in the region;

$k_{\square}$ is the input-output coefficient;

$P$ is the mid-year population in the region;
$N_{\square}$ is the minimum recommended dietary intake $^{8}$.

The proposed accessibility index $(F)$ is based on the comparison of the market size calculated by using the medical norms, population size and the actual local production volume for the given food item.

a) $F>1$ means that the local production volume is sufficient and able to meet the local demand;

b) $F<1$ means that the local production volume is insufficient.

It should be noted that the raw materials for food markets are not turned entirely into finished food products, a part of these materials (seeds, livestock feed, young growth for internal production) is used for companies' own consumption. Therefore, in research literature it is recommended to consider economic entities in terms of full food production, that is, to consider all their production as commodities [6;7]. In our study we are going to calculate this indicator by using the milk and dairy market of a Russian region - the Republic of Tatarstan. We are also going to conduct a matrix analysis to determine the best priority areas for the national industrial and competition policies.

\section{Results}

In order to estimate food supply in the food market we need to take into account such indicator as food affordability and the following socio-economic indicators: the purchasing power of the population in relation to milk and dairies; the share of milk and dairy products expenditures; the milk price index; the average producer prices; and the average consumer prices. These indicators characterize the affordability of the

\footnotetext{
${ }^{8}$ Recommended dietary intake levels corresponding to the modern nutrition standards (approved by the Ministry of Healthcare of the Russian Federation of 19 August 2016 No. 614).
}

Socio-economic indicators characterizing the affordability and accessibility of milk and dairies Table 1 in Tatarstan in 2011-2017

\begin{tabular}{|c|c|c|c|c|c|c|c|c|}
\hline Year & $\begin{array}{l}\text { Milk ac- } \\
\text { cessibility } \\
\text { index }\end{array}$ & $\begin{array}{c}\text { Per capita } \\
\text { consumption } \\
\text { of milk and } \\
\text { dairies, } L\end{array}$ & $\begin{array}{l}\text { Purchasing power of the } \\
\text { population in relation to } \\
\text { milk, dairies, butter and } \\
\text { margarine, } L\end{array}$ & $\begin{array}{c}\text { Share of } \\
\text { expenditures } \\
\text { for milk and } \\
\text { dairies, } \%\end{array}$ & $\begin{array}{l}\text { Raw cow's } \\
\text { milk price } \\
\text { index, \% }\end{array}$ & $\begin{array}{l}\text { Average pro- } \\
\text { ducer prices } \\
\text { for raw cow's } \\
\text { milk, rbs/ton }\end{array}$ & $\begin{array}{l}\text { Average con- } \\
\text { sumer prices } \\
\text { for raw cow's } \\
\text { milk, rbs/L }\end{array}$ & $\begin{array}{l}\text { Consumer } \\
\text { price index } \\
\text { of milk and } \\
\text { dairies, } \%\end{array}$ \\
\hline 2010 & 0.81 & 368 & 1120 & 5.0 & 141.0 & 11902 & 25.28 & 119.0 \\
\hline 2011 & 0.78 & 367 & 1226 & 4.2 & 85.9 & 12635 & 25.87 & 101.3 \\
\hline 2012 & 0.77 & 367 & 1408 & 4.0 & 101.7 & 11789 & 27.89 & 104.4 \\
\hline 2013 & 0.70 & 364 & 1374 & 3.5 & 150.2 & 14269 & 35.81 & 121.5 \\
\hline 2014 & 0.75 & 364 & 1343 & 3.8 & 103.1 & 18361 & 36.79 & 108.1 \\
\hline 2015 & 0.77 & 362 & 1249 & 4.0 & 100.2 & 18644 & 39.52 & 109.6 \\
\hline 2016 & 0.79 & 362 & 703 & 4.5 & 120.9 & 20253 & 41.28 & 108.0 \\
\hline
\end{tabular}

Source: Regional Office of the Federal State Statistics Service in the Republic of Tatarstan. Retrieved from: http://tatstat.gks.ru 
given food item for local communities. Table 1 shows the data for each of these indicators in $\mathrm{Ta}$ tarstan.

The situation in the regional market of milk and dairy products looks promising although the region does not meet the required $90 \%$ of self-reliance stipulated by the Doctrine ${ }^{9}$. As Table 1 illustrates, the current level of self-reliance for milk and dairies in Tatarstan is $70-81 \%$. In the given period, the level of accessibility of locally produced milk for the local community was $77 \%$.

We calculated the coefficients of correlation between the indicators of concentration (HHI and market concentration for profit, production volume in physical terms and gross profit) and the key socio-economic indicators reflecting the accessibility and affordability of milk and dairies in the region. Table 2 shows the statistically significant correlation coefficient for the milk market.

Coefficients of paired linear correlation between the socio-economic indicators and the level of concentration on the milk market in Tatarstan from the beginning of 2011 to 2017

\begin{tabular}{|l|r|r|r|r|r|r|}
\hline Indicators & $\begin{array}{c}\text { HHI in } \\
\text { phy- } \\
\text { sical } \\
\text { terms }\end{array}$ & $\begin{array}{c}\text { HHI } \\
\text { for } \\
\text { gross } \\
\text { profit }\end{array}$ & $\begin{array}{c}\text { HHI } \\
\text { for net } \\
\text { profit }\end{array}$ & $\begin{array}{c}\text { CR3 in } \\
\text { phy- } \\
\text { sical } \\
\text { terms }\end{array}$ & $\begin{array}{c}\text { CR3 } \\
\text { for } \\
\text { gross } \\
\text { profit }\end{array}$ & $\begin{array}{c}\text { CR3 } \\
\text { for } \\
\text { net } \\
\text { profit }\end{array}$ \\
\hline $\begin{array}{l}\text { Share of ex- } \\
\text { penditures } \\
\text { on milk } \\
\text { and dairies }\end{array}$ & 0.74 & 0.67 & 0.27 & 0.66 & 0.57 & 0.10 \\
\hline
\end{tabular}

We found that the milk market in Tatarstan was characterized by a strong correlation between the HHI in physical terms and the share of expenditures on milk and dairies. This correlation looks the following way:

$$
y=3,3+42,74 \cdot x_{8}
$$

where is the share of expenditures on milk and dairies;

$x_{8}$ is the HHI for the milk market in physical terms.

This regression equation is statistically robust and leads us to the conclusion that an increase in the concentration of producers on the market will have a negative influence on the affordability and accessibility of milk.

${ }^{9}$ Decree of the President of the Russian Federation of 30.01.2010 No. 120 "On the Food Security Doctrine of the Russian Federation" Retrieved from: http://base.garant.ru/1217271
If we take into consideration the fact that food producers receive state support in almost all countries, it is pertinent to evaluate the impact of economic entities' efficiency on the accessibility index.

According to the non-linear regression equations, in the milk market, producers' profitability has a positive impact on the accessibility index, although the model explains only $16 \%$ of the dependent variable and looks the following way:

$$
\ln y=1,37+0,67 \cdot \ln x_{14}
$$

where $y$ is the index of milk accessibility;

$x_{14}$ is milk producers' profitability.

This regression equation is statistically robust and we can interpret it the following way: producers' efficiency has a negligible impact on the accessibility index, which means that milk producers can enhance the level of milk accessibility considerably only if their real production volumes increase. Such qualitative indicators as price and cost per unit or subsidies do not affect the index of accessibility.

In terms of regional food security, the development of regional food markets entirely depends on the development of the constituting local markets [8]. The existing research literature, however, does not give us a clear understanding of this category [9-12]. For our analysis we used municipal districts of Tatarstan as equivalents for local markets [13]. This approach takes into account the common conditions in which producers operate and the distribution logistics [14].

\section{Conclusion}

Milk production in Tatarstan is characterized by the following: the average production profitability is $20 \%$, the average level of the accessibility index calculated for 43 local markets of the region is 1.95 .

In order to choose the optimal tools for the competition policy and agro-industrial policy for this region, we have applied a decision matrix method. Local markets (with their own food production) are placed in the matrix, where the diameter of the figure is the $\mathrm{HHI}$ for the production volume in physical terms; the $\mathrm{x}$-axis corresponds to producers' profitability; and the y-axis, to the accessibility of the food item. The origin of y-axis is 1 in order to identify those municipal districts where the local demand for the food item is satisfied by local producers. Recommended measures are going to be chosen depending on which quadrant this or that district belongs to. 


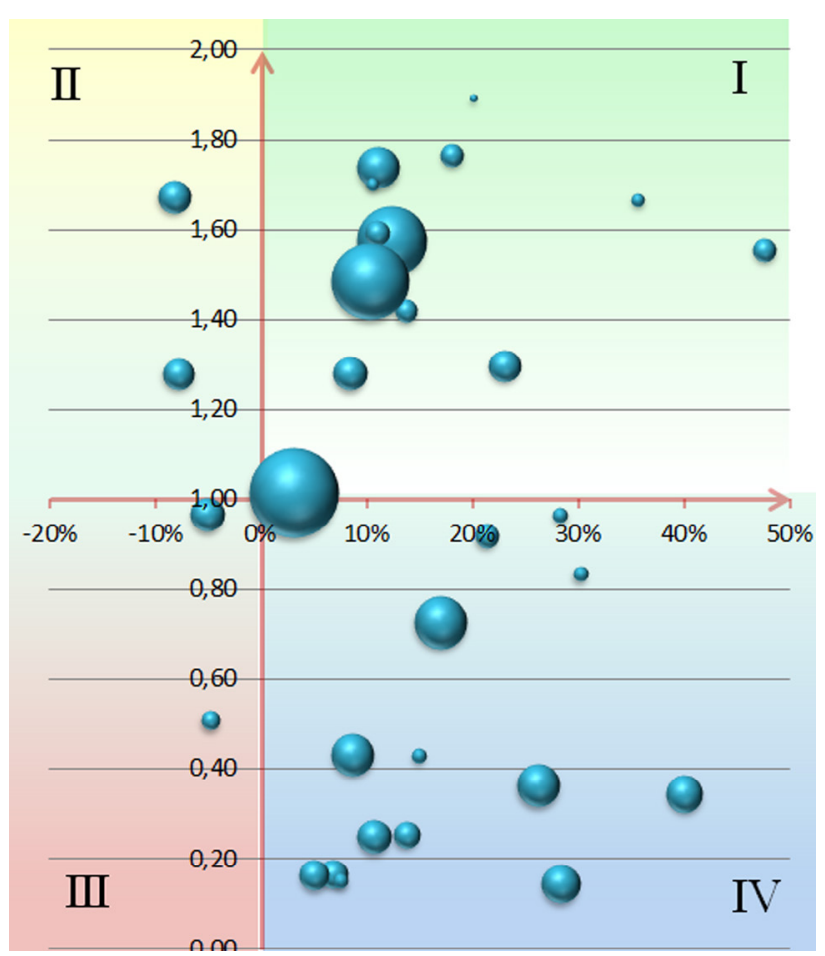

Figure 1. Decision matrix for the selection of priorities for the agro-industrial and competition policies in regional milk production

The first quadrant (index of accessibility $>1$; profitability $>0$ ) comprises 26 local markets or $63 \%$ of the local economic entities out of 336 . The economic entities proved to be the most efficient in Kukmorsky District (59\%) while the highest accessibility index was in Atninsky District (12.40), which means that in 26 districts of Tatarstan governmental policies should be aimed at supporting new and relatively small economic entities and at stimulating competition. Farmers are currently facing a number of issues which should be addressed on the national but also on the municipal level: it is necessary to lower the bureaucratic barriers to starting a business, provide subsidies not only for large producers but also for smaller ones (at the moment livestock subsidies are granted depending on the number of livestock heads in a certain territory). Consumers are ready to pay more for higher quality foods and to go on-line to buy fresh produce. Therefore, farmers should be offered assistance regarding distribution channels and logistics management. This would stimulate the development of smaller enterprises and enable them to compete with larger ones. In developed regions, wholesale merchants buy produce from farmers with a higher profit margin than factories [18].

The second quadrant (index of accessibility > 1 ; profitability $<0$ ) includes loss-making districts
Zainsky and Sarmanovsky with an average loss of $8 \%$. However, the accessibility index for these districts is 1.5. In these local markets there are seven economic entities. We believe that it is necessary to support the existing economic entities (formation of large entities) in order to enhance the profitability of production and help farmers stay afloat. Moreover, as our regression analysis has shown, an increase in profitability has a positive impact on accessibility of foods while market monopolization leads to an insignificant increase in consumers' expenditures on milk and dairies.

The third quadrant (index of accessibility $<1$; profitability $<0$ ) includes Cheremshansky and Aznakaevsky districts (21 economic entities or 6\%). Since it is essential to ensure accessibility and affordability of food in the region, it is necessary to support large and already existing producers in order to reach the level of the accessibility index corresponding to the reference daily intake. Since the companies in the third quadrant are unprofitable, the government can choose to focus on maintaining the existing producers and enhancing their efficiency (this measure can prove to be effective since an increase in profitability and in subsidies leads to an increase in the accessibility of foods).

The fourth quadrant (index of accessibility $<1$; profitability $>0$ ) includes 14 local markets. The average production profitability of $18 \%$ is characteristic of $27 \%$ of milk producers in the republic. Nevertheless, the 14 local markets in this quadrant fail to provide the necessary level of accessibility of locally produced foods. In this case, the optimal solution would be to focus on ensuring the required level of accessibility of locally produced foods. For example, in Bavlinsky, Rybno-Slobodsky, Laishevsky and Verkhneuslonsky districts, where the accessibility index equals 1 , measures should be taken to develop competition. In the remaining districts, it is recommended to support the existing producers.

Our results demonstrate that the decision matrix method is quite effective for planning soft state regulation in food production. These results, however, should be interpreted with a certain caution since the data used for our analysis were limited to the specific region. Nevertheless, this approach can be applied to the study of other regions and countries. The above-described matrices, which include indicators of competition and socio-economic indicators, can be used to devise governmental policies and programs to enhance food security on the national, regional and local levels. 


\section{References}

1. Alexandratos, N. et al. (2009) Food and Agricultural Organization of the United Nations [FAO]. Retrieved from: http://www.fao.org/

2. Storozh I. A. (2016) Lean manufacturing implementation algorithms. Standards and quality, (11), 58-60. Retrieved from: http://www.ria-stk.ru/stq/adetail.php?ID=106223

3. Kudryashov A. Lean manufacturing. Bulletin of Unido in Russia. Retrieved from: http://www. unido-russia.ru/archive/num6/art6 14/

4. Turgel, I. D., Bozhko, L. G, \& Linshi, S. (2016). State support for single-industry towns' development of Russia and Kazakhstan. Finance: Theory and Practice, 2(92), 22-32. (In Russ.)

5. Schumpeter, J. (1934). The theory of economic development Harvard University Press. Cambridge, MA.

6. Nijbroek, R. P., \& Andelman, S. J. (2016) Regional suitability for agricultural intensification: a spatial analysis of the Southern Agricultural Growth Corridor of Tanzania. International Journal of Agricultural Sustainability, 14(2), 231-247. DOI: 10.1080/14735903.2015.1071548

7. Haggblade, S., Me-Nsope, N. M., \& Staatz, J. M. (2017) Food security implications of staple food substitution in Sahelian West Africa. Food Policy, 71, 27-38. DOI: 10.1016/j.foodpol.2017.06.003

8. Croppenstedt, A., Bellú, L. G., Bresciani, F., \& DiGiuseppe, S. (2007) Agricultural Policy Impact Analysis with Multi-Market Models: A Primer ESA Working Paper No. 07-26, June 2007. FAO, Rome.

9. Bernardina A., Matthias K., Nicolas K. (2017) A tale of two tails: Explaining extreme events in financialized agricultural markets. Food Policy, 69, 256-269. DOI: $\underline{10.1016 / j . f o o d p o l .2017 .05 .004}$

10. Namany, S., Al-Ansari, T., \& Govindan, R. (2019) Optimisation of the energy, water, and food nexus for food security scenarios. Computers and Chemical Engineering, 129, 106513. DOI: 10.1016/j.compchemeng.2019.106513

11. Ambagna, J. J., Kane, G. Q., \& Oyekale, A. S. (2012) Subsistence farming and food security in Cameroon: A macroeconomic approach. Life Science Journal, 9(4), 3949-3954.

12. Alpas, H., \& Kiymaz, T. (2012) Defending the Safety of the Global Food System: Advances in Food Security and Safety. NATO Science for Peace and Security Series C: Environmental Security, $122,1-9$.

13. Safiullin, A. R., Shakirzyanov, N. R., \& Ravzieva, D. I. (2018) Infrastructure for regional development investment projects. Journal of Social Sciences Research, (Special Issue 1), 281-284. DOI: 10.32861/jssr.spi1.281.284

14. Selischeva, T. A., \& Dyatlov, S. A. (2014) Regional and Spatial Characteristics and Ways of Overcoming Digital Inequality in Russia. Ekonomika obrazovaniya, (2), 48-52. (In Russ.)

15. Lang, T., \& Barling, D. (2012) Food security and food sustainability: Reformulating the debate. Geographical Journal, 178(4), 313-326. DOI: 10.1111/j.1475-4959.2012.00480.x

\section{Information about the author}

Aigul I. Sabirova - Senior Lecturer, Institute of Management, Economics and Finance, Kazan Federal University (18 Kremlevskaya Str., Kazan 420008, Tatarstan, Russia); e-mail: aigylkinyes@ mail.ru

Marat M. Nizamutdinov - PhD in Economics, Associate Professor, Institute of economics, Kazan State Agrarian university (65 Karl Marx Str., Kazan, 420015, Tatarstan, Russia); e-mail: marat181@rambler.ru

Azat R. Safiullin - Doctor in Economics, Associate Professor, Institute of Management, Economics and Finance, Kazan Federal University (18 Kremlevskaya Str., Kazan 420008, Tatarstan, Russia); e-mail: safiullin.ar@gmail.com

Firdaus I. Harisova - Doctor in Economics, Professor, Institute of Management, Economics and Finance, Kazan Federal University (18 Kremlevskaya Str., Kazan 420008, Tatarstan, Russia); e-mail: firdavsun@mail.ru

ARTICLE INFO: received June 7, 2019; accepted September 03, 2019 


\section{Информация об авторе}

Сабирова Айгуль Ильшатовна - старший преподаватель Института управления, экономики и финансов Казанского федерального университета (420008, Россия, Татарстан, Казань, ул. Кремлёвская, 18); e-mail: aigylkinyes@mail.ru

Низамутдинов Марат Мингалиевич - кандидат экономических наук, доцент Института экономики Казанского государственного аграрного университета (420015, Россия, Татарстан, Казань, ул. Карла Маркса, 65); e-mail: marat181@rambler.ru

Сафиуллин Азат Рашитович - доктор экономических наук, доцент Института управления, экономики и финансов Казанского федерального университета университета (420008, Россия, Татарстан, Казань, ул. Кремлёвская, 18); e-mail: safiullin.ar@gmail.com

Харисова Фирдаус Ильясовна - доктор экономических наук, профессор Института управления, экономики и финансов Казанского федерального университета университета (420008, Россия, Татарстан, Казань, ул. Кремлёвская, 18); e-mail: firdavsun@mail.ru

ИНФОРМАЦИЯ О СТАТЬЕ: дата поступления 7 июня 2019 г.; дата принятия к печати 3 сентября 2019 г.

This work is licensed under a Creative Commons Attribution 4.0 International License

Эта работа лицензируется в соответствии с Creative Commons Attribution 4.0 International License 